\title{
Arabic language learning reconstruction as a response to strengthen Al-Islam studies at higher education
}

\author{
Mahyudin Ritonga ${ }^{1}$, Hendro Widodo ${ }^{2}$, Munirah $^{3}$, Talqis Nurdianto ${ }^{4}$ \\ ${ }^{1}$ Faculty of Islamic Studies, Universitas Muhammadiyah Sumatera Barat, Indonesia \\ ${ }^{2}$ Postgraduate Program of Islamic Education, Universitas Ahmad Dahlan, Indonesia \\ ${ }^{3}$ Postgraduate Program of Indonesian Language Education Study, Universitas Muhammadiyah Makassar, Indonesia \\ ${ }^{4}$ Faculty of Language Education, Universitas Muhammadiyah Yogyakarta, Indonesia
}

\begin{tabular}{l}
\hline \hline Article Info \\
\hline Article history: \\
Received May 24, 2020 \\
Revised Nov 9, 2020 \\
Accepted Jan 23, 2021
\end{tabular}

Keywords:

Al-Islam

Curriculum

Evaluation

Learning Arabic

\begin{abstract}
Knowledge of the Islam at every student is supported by many factors, one of which is the Arabic language compentence. This research aimed to evaluate and find Arabic language learning construction in strengthening al-Islam at higher education. The desire to find the construction is because there is no visible connection between Arabic language learning and al-Islam learning so that clarity of learning objectives, learning materials, learning implementation, and evaluation systems of Arabic language learning at higher education is needed. In line with this purpose, this study used a qualitative method with a phenomenological approach. The sources of data were facts, Arabic language lecturers, al-Islam lecturers, and students purposively. Data were analyzed by using critical realism. The results of the study proved that the reconstruction of learning objectives, materials, implementation, and evaluation systems is needed to realize Arabic language learning that can strengthen al-Islam at higer education.
\end{abstract}

This is an open access article under the CC BY-SA license.

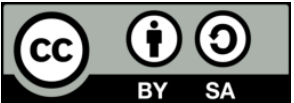

\section{Corresponding Author:}

Mahyudin Ritonga

Faculty of Islamic Studies

Universitas Muhammadiyah Sumatera Barat

West Sumatera, Padang 25172, Indonesia

Email: mahyudinritonga@gmail.com

\section{INTRODUCTION}

Muhammadiyah Universities (PTM) have the same identity in terms of curriculum, where all universities make Al-Islam and Kemuhammadiyahan or AIK as an institution curriculum because the existence of $A I K$ is the forerunner to the existence of Muhammadiyah Universities [1], so PTM exists because there is $A I K$ [2]. AIK exists because of the existence of Muhammadiyah as the struggle of $\mathrm{KH}$ Ahmad Dahlan. Thus the objective of $A I K$ as a state of mind is to be a true Muslim, to be a good Muslim (progressive and philanthropic), a religious mover in the community and a leader [3].

While Arabic for Muhammadiyah Universities has not become a Muhammadiyah Universities curriculum like AIK. However, a number of Muhammadiyah Universities have made it into an institutional curriculum, this needs to be appreciated because of the importance of language skills for students [4]. Language skills have become a demand in the era of globalization which is full of competition $[5,6]$.

In line with the urgency of language skills, Muhammadiyah Universities are demanded to be able to strengthen Al-Islam and Kemuhammadiyahan through innovations in learning that are related to Al-Islam and Kemuhammadiyahan. Among the many subjects that are closely related to Al-Islam and 
Kemuhammadiyahan, the Arabic language is chosen, because the foundation of Islamic teachings uses Arabic.

The relationship between Arabic and Islamic teaching sources as explained above shows that quality Arabic language learning can strengthen and improve the quality of Al-Islam and Kemuhammadiyahan learning. However, this study highlighted Arabic language learning at various faculties at Muhammadiyah University of West Sumatra which were not qualified [4]. The statement that arises from reality becomes a question because how is it possible for certain subjects that are lacking in quality to contribute or strengthen other subjects.

Poor quality Arabic language learning does not only occur at Muhammadiyah Universities, but even the same conditions also occur in various Islamic education institutions [7] and Islamic universities (PTKAI) [8] which mostly use Arabic literature study sources. Apart from the same conditions between PTMA and PTKAI in terms of Arabic language learning, then to strengthen Al-Islam at PTMA can be performed through innovation and reconstruction of Arabic language learning.

Reconstruction of learning means finding the right Arabic language learning construct to strengthen Al-Islam and Kemuhammadiyahan. The construction that will be found includes objectives, learning material, learning implementation and evaluation. Finding objectives of Arabic language learning is the most important thing to do because the clarity of objectives will affect other aspects of learning. Objectives of Arabic language learning as the opinions of experts are inseparable from linguistic competence (al-kifayah al-lughawiyyah), communicative competence (al-kifayah al-ittishaliyyah) and cultural competence (alkifayah al-tsaqafiyyah) [9]. Linguistic competence (al-kifayah al-lughawiyyah) includes four language skills namely the hearing skills (maharah al-istima), speaking skills (al-maharah al-kalam), reading skills (almaharah al-qiro'ah) and writing skills (al-maharah al-kitabah) [10]. The communicative and cultural competence is marked by the skills of students to interact with native speakers (Arabs), or at least, interact with Arabic-language works that are certainly in accordance with Arabic culture, in addition to a universal culture that does not conflict with the principles of teaching Islam.

The three objectives above are certainly not possible to apply to Arabic language learning which is only one course from dozens of other courses. Therefore, an in-depth analysis of the Arabic language learning objectives to be achieved needs to be established. In determining the objectives of Arabic language learning, at least take into consideration the culture of the target language, the needs of the Indonesian people for Arabic, pay attention to the psychology of students related to their interests, motivations, and needs for Arabic, as well as the skills and level of mastery of Arabic, the relationship between Indonesian and Arabic including similarities and differences between the two languages.

The second aspect whose construction needs to be found in Arabic language learning at PTMA is learning material. The unclear objective of Arabic language learning as implemented at PTMA affects the learning material that is presented, where the lecturer does not have a clear foundation in choosing learning resources and the content of the material as outlined in the semester learning plan (RPS).

The construction aspects of the implementation of Arabic language learning in this study are related to the time, methods, techniques, and media that should be used by lecturers in learning, some of these aspects can make learning run effectively because it is related to the learning atmosphere. Furthermore, related to evaluation, the evaluation system in Arabic language learning at PTMA also does not yet have a clarity about the language skills to be measured [11], therefore an evaluation construction that can be applied at PTMA is needed.

Siginficance of this study is recent data showed that the number of Muhammadiyah Universities in Indonesia was 174, where Al-Islam and Kemuhammadiyahan (AIK) couse in all PTMA are institutional spirits so that all elements in the institution are expected to strengthen $A I K$. Arabic language as part of the institutional curriculum is seen as one of the important aspects in strengthening the $A I K$, so to realize it requires a complex study on the form of learning construction. The results of this study can be a reference for 174 PTMA and a foundation for Muhammadiyah Headquarter in positioning Arabic language to strengthen $A I K$ in the universities managed.

In accordance with the problems expressed above, this study has several objectives namely: 1) Finding objectives of Arabic language learning construction in strengthening AIK at PTMA; 2) Finding Arabic language learning material in strengthening AIK at PTMAI; 3) Finding the construction of Arabic language learning implementation in strengthening AIK at PTMA; 4) Finding the construction of Arabic language learning evaluation system in strengthening $A I K$ at PTMA. Nationally, the research has been beneficial to the head of Muhammadiyah's central leadership in setting the policy for all PTMA, while internationally the results of this research can serve as a cornerstone in making the formulation of Arabic language learning material that is not fixed in grammaticium problems. 


\section{RESEARCH METHOD}

This study used a qualitative approach because study data are related to reality which can be described through words and sentences. This study used critical realism approach, which is a study approach to make a criticism of reality based on scientific theories by considering epistemology and ontology.

The sources of this study were Arabic language lecturers, students, phenomena, and literature related to the focus of the study; therefore, the number of research informant are 14 coupled with four researchers. Data were collected by using observation, interview, and documentation study as well as focus group discussions. The stages undertaken in this study can be seen in Figure 1.

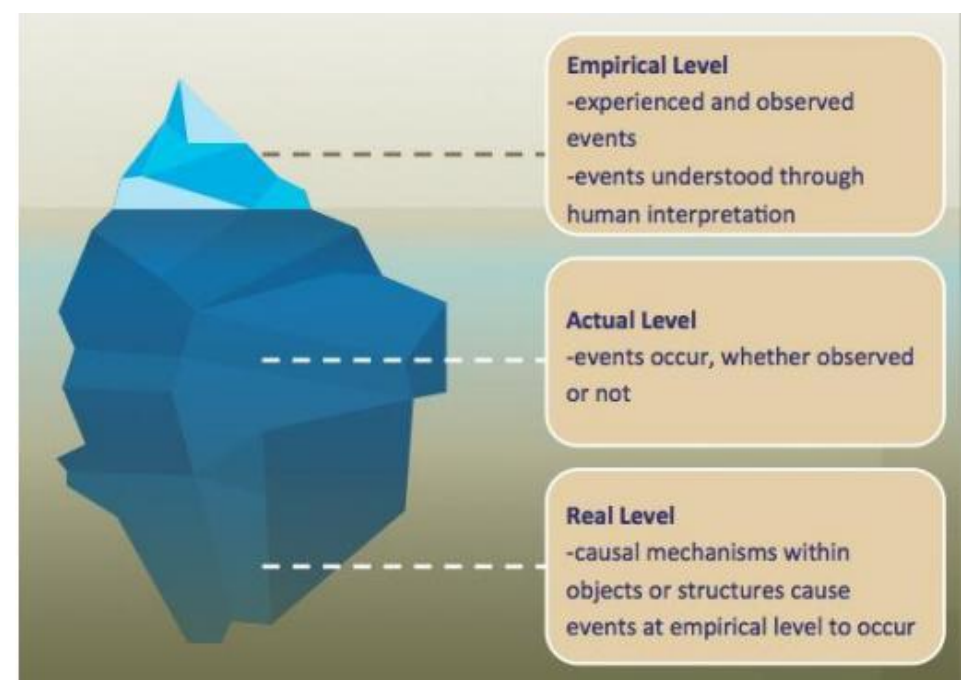

Figure 1. Reality critique concept [12]

Data analysis technique used critical realism related to Arabic language learning on objectives, material, implementation, and evaluation based on scientific theory which was then linked to Al-Islam and Kemuhammadiyahan at PTMA. A scientific theory is used as a basis for critics as a strategy to determine the objectives of language learning, the foundation relating to the preparation and selection of language learning materials, theories related to the learning implementation, and theories related to learning evaluation systems.

To examine the data validity, this study used triangulation of sources, times, and techniques. The intention is that the research data obtained from certain informant is verified to other informant, the data obtained at a certain time is controlled during the time of the research, while the intended by the triangulation technique is researchers examine the data obtained from interviews with observations, documentation, focus group discussion (FGD) and vice versa, researchers make a statement when it has been versed through the data collection techniques used.

\section{RESULTS AND DISCUSSION}

The results of the study through observation, interviews, documentation and focus group discussions show that the reality of Arabic language learning at PTMA can be seen in Table 1. Table 1 presents that the reality of Arabic language learning at PTMA requires a new construct, moreover associated with the strengthening of Al-Islam and Kemuhammadiyahan. 
Table 1. Reality of Arabic language learning at PTMA

\begin{tabular}{|c|c|c|c|c|}
\hline \multirow{2}{*}{ Aspect } & \multicolumn{4}{|c|}{ Result } \\
\hline & Observation & Interview & Documentation study & FGD \\
\hline \multirow[t]{2}{*}{$\begin{array}{l}\text { Arabic language } \\
\text { learning } \\
\text { objectives }\end{array}$} & $\begin{array}{l}\text { There is no uniformity } \\
\text { of objectives agreed } \\
\text { and carried out }\end{array}$ & $\begin{array}{l}\text { PTMA leaders provide } \\
\text { lecturers to determine } \\
\text { Arabic language } \\
\text { learning objectives }\end{array}$ & $\begin{array}{l}\text { There are no documents } \\
\text { related to the determination } \\
\text { of Arabic language learning } \\
\text { objectives at PTMA }\end{array}$ & $\begin{array}{l}\text { Arabic language learning } \\
\text { objectives need to be } \\
\text { determined by the Council of } \\
\text { Higher Education, Research } \\
\text { and Development of } \\
\text { Muhammadiyah }\end{array}$ \\
\hline & $\begin{array}{l}\text { Arabic language } \\
\text { learning is not } \\
\text { connected to } A I K\end{array}$ & $\begin{array}{l}\text { - Each Arabic lecturer } \\
\text { has a different view } \\
\text { - Students do not } \\
\text { know Arabic } \\
\text { language learning } \\
\text { objectives clearly }\end{array}$ & $\begin{array}{l}\text { Each lecturer has a } \\
\text { different learning tools }\end{array}$ & $\begin{array}{l}\text { Arabic language learning } \\
\text { integrated with other courses } \\
\text { in strengthening } A I K \text { is } \\
\text { needed }\end{array}$ \\
\hline $\begin{array}{l}\text { Arabic language } \\
\text { learning } \\
\text { material }\end{array}$ & $\begin{array}{l}\text { In general, Arabic } \\
\text { language lecturers use } \\
\text { two learning resources } \\
\text { at various faculties, } \\
\text { namely al- 'arabiyyah } \\
\text { bayna yadayk and al- } \\
\text { 'arabiyyah linnasyiin }\end{array}$ & $\begin{array}{l}\text { - The lecturer has not } \\
\text { compiled Arabic } \\
\text { language learning } \\
\text { resources. } \\
\text { - Students find it } \\
\text { difficult to use } \\
\text { learning resources }\end{array}$ & $\begin{array}{l}\text { The material in both } \\
\text { sources is chosen by the } \\
\text { lecturer according to what } \\
\text { is considered important }\end{array}$ & $\begin{array}{l}\text { - The themes in AIK can } \\
\text { be used as a reference in } \\
\text { compiling Arabic } \\
\text { language material } \\
\text { - The topics in AIK are } \\
\text { chosen according to } \\
\text { Arabic language credit }\end{array}$ \\
\hline $\begin{array}{l}\text { Learning } \\
\text { implementation }\end{array}$ & $\begin{array}{l}\text { Lecturers only use } \\
\text { formal lecture time }\end{array}$ & $\begin{array}{l}\text { - There is no Arabic } \\
\text { language unit at } A I K \\
\text { institution } \\
\text { - Students and } \\
\text { lecturers only } \\
\text { interact in Arabic } \\
\text { during lectures }\end{array}$ & $\begin{array}{l}\text { - Learning tools and } \\
\text { syllabus cannot be used } \\
\text { as references in learning } \\
\text { implementation } \\
\text { - The method and media } \\
\text { used are not relevant }\end{array}$ & $\begin{array}{l}\text { - The existence of Arabic } \\
\text { units at } A I K \text { institutions is } \\
\text { needed } \\
\text { - Learning implementation } \\
\text { outside of class hours } \\
\text { becomes important, such } \\
\text { as courses }\end{array}$ \\
\hline $\begin{array}{l}\text { Arabic language } \\
\text { learning } \\
\text { evaluation }\end{array}$ & $\begin{array}{l}\text { The evaluation } \\
\text { system is only } \\
\text { carried out during the } \\
\text { mid-exam and final } \\
\text { exam }\end{array}$ & $\begin{array}{l}\text { - The lecturer } \\
\text { compiles the } \\
\text { questions } \\
\text { - There is no } \\
\text { consideration of } \\
\text { differences in skills }\end{array}$ & $\begin{array}{l}\text { - Documented questions } \\
\text { only have objectives and } \\
\text { essays }\end{array}$ & $\begin{array}{l}\text { - An evaluation of Arabic } \\
\text { language abilities needs } \\
\text { to be performed to } \\
\text { prospective PTMA } \\
\text { students. } \\
\text { - Evaluation instruments } \\
\text { must be able to measure } \\
\text { Arabic language } \\
\text { competence }\end{array}$ \\
\hline
\end{tabular}

\subsection{Arabic language learning objectives in strengthening $A I K$ at PTMA}

In various opinions, the most important function of Arabic language is as a means of communication between Arabic society, as well as for other parties who wish to communicate with them [13]. Therefore, the main objective of Arabic language learning in an educational institution such as at PTMA so that students when completing the learning program is not only mastering Arabic grammar but have the skills to use Arabic language as a means of communication with the Arabs, at a minimum, communicating with Arabic language literary works.

Skills include listening (al-istima'), speaking (al-kalam), reading (al-qiro'ah), and writing (alkitabah) [14] are expected to be possessed by students or there is an emphasis on one skill according to the study time available and in accordance with the needs of students. To achieve the objective or graduate competence standard (SKL), a textbook is prepared by the lecturer team or by other parties.

The results of the study showed that the achievement of Arabic language students who studied Arabic language was not as expected, this reality showed Arabic language learning had not been implemented effectively. This unsatisfactory result is caused by many factors involved in learning, ranging from objectives (al-ahdaf), learning material (al-muhtawi), learning methods and techniques (al-thuruq wa asalib al-tadris) and evaluation (at-taqwim). Likewise on the human factor, namely student factors and educator factors (almudarris wa al-thullab). This problem seems to be in line with various Arabic language learning problems as stated by El-Omari [15].

In dealing with these problems, most higher education based on studies or observations considers textbooks as the root of the problem. It can be seen that many of the higher education 'turn' to find a 'breakthrough' or 'short cut' [16]. The effort was carried out by 'replacing textbooks' which had been used with other textbooks whose compatibility was not yet known to improve the effectiveness of learning because it was chosen not through careful study or evaluation.

The stage carried out in finding the solution is certainly not right, it should start from a review of the learning objective (al-ahdaf), because in learning as a system, the objective is the basis for the selection of learning material (al-muhtawy) and even becomes the basis also for the selection of learning method 
(al-thuruq) which functions as a way to teach material. Evaluation is also (al-taqwim) based on objectives and at the same time as a stage to find out the objectives achieved. Therefore, the discussion of textbooks means discussing the learning system which is also a sub-system of the curriculum or syllabus, which includes a discussion of learning objectives, learning materials, learning methods, and evaluation.

Related to the strengthening of Al-Islam and Kemuhammadiyahan at PTMA, Arabic language learning objectives can be directed to increase the skills of students in knowing the vocabulary, conversations, and verses of the Qur'an relating to Al-Islam and Kemuhammadiyahan. This is intended so that students are presented with Arabic language material and understand $A I K$. This rationale is inseparable from the relevance of Islamic teachings using sources from Arabic language [17], a Muslim will find it difficult to understand the teachings of religion without having the skills of Arabic language as a tool to understand it $[18,19]$.

Learning objectives must be determined by considering the needs of the community who will learn $[20,21]$, this is in accordance with the conditions of students at PTMA who need Al-Islam and Kemuhammadiyahan learning. Determination of learning objectives must be based on consideration of student psychology [21], student motivation [22], habits in the real world experienced by students [23]. Some of these criteria seem appropriate to be used as a basis for determining the Arabic language learning objective to strengthen Al-Islam and Kemuhammadiyahan at PTMA. Psychologically, students have a close relationship with Arabic language in various life activities, such as reading the Qur'an before starting lectures, but this habit will not have much effect on the knowledge of Islamic studies if it is not wellprogrammed in the form of curriculum.

The next criterion is student motivation, based on the results of interviews with students, student motivation to learn Arabic language is religious motivation, because students feel Islam is inseparable from Arabic language, this is not true because any religion in the world is not affiliated with the language, and there is no religion that prohibits its adherents to learn certain languages. On the other hand, the views of students can be accepted, because the Qur'an and the Hadith as sources of Islamic teachings are in Arabic language, Islamic teachings books in various fields are also written with Arabic languages, such as theology, Islamic law, fiqh, interpretation and so on.

There is also a desire to learn Arabic language due to the desire to exist in Muhammadiyah. Among the councils in Muhammadiyah, there are tarjih and tajid council [11], this council requires human resources who have the skills in foreign languages such as Arabic language and English. Because tarjih and tajdid assembly are tasked to issue decisions on actual problems in society. Decisions can be found through a study of propositions that are relevant to current issues.Student motivation as explained above can be used as a basis in determining Arabic language learning objectives to strengthen the learning of Al-Islam and Kemuhammadiyahan. In addition, the results of discussions with lecturers of Arabic language and $A I K$ also obtained an agreement that led to the interconnection between Arabic language and Al-Islam and Kemuhammadiyahan in PTMA like the existence of subjects in Muhammadiyah elementary schools, junior high schools, and senior high schools incorporated in ISMUBA curriculum (Islam, Kemuhammadiyahan, and Arabic language). This agreement then demands the existence of Arabic language units at $A I K$ institutions in every PTMA.

\subsection{Arabic language learning material in strengthening AIK di PTMA}

After knowing Arabic language learning objectives at PTMA as described above, the learning material is also adjusted to the values of Al-Islam and Kemuhammadiyahan. PTMA through the Council of Higher Education, Research and Development of Muhammadiyah has established four AIK courses, namely $A I K$ 1, AIK 2, AIK 3 and $A I K 4$, the value and content of each $A I K$ is different from the guidelines issued by the Council of Higher Education, Research and Development of Muhammadiyah. The provisions of the Council of Higher Education, Research, and Development of Muhammadiyah are found in $A I K$ implementation at PTMA, so Arabic language material only requires connectivity with $A I K$. The form of connectivity obtained from focus group discussions between Arabic language lecturers and AIK lecturers uses the AIK guide book [24] which can be seen in Table 2. 
Table 2. AIK topics that need to be loaded in Arabic learning materials

\begin{tabular}{|c|c|c|}
\hline No. & $A I K$ learning material & Arabic language learning material \\
\hline 1 & Islam as a way of life & الاسلام ومايتعلق به \\
\hline 2 & Human nature in the Islamic view & الانسان عند الاسلام \\
\hline 3 & Faith and influence in life & الايمان و أثره فى الحياة \\
\hline 4 & Monotheism and its urgency for Muslim life & التوحيد و أهميته في حياة المسلمين \\
\hline 5 & The concept of aqidah in Islam & منهج العقيدة عند الآسلام \\
\hline 6 & Shirk and its dangers for humans & الشرك الش \\
\hline 7 & Purpose of worship & العبادة وحقيقتها \\
\hline 8 & Morality & الاخلاق \\
\hline 9 & Muamalah & المعاملة \\
\hline 10 & The History of Muhammadiyah & محمدية وتاريخها \\
\hline 11 & Personality of Muhammadiyah & خصائص محمدية \\
\hline 12 & Muhammadiyah as a social movement & محمدية وحركة الانسانية \\
\hline 13 & Muhammadiyah as an education movement & محمدية وحركة التربية \\
\hline 14 & Science and technology in the Islamic view & التكنولوجيات و المعلومات و الاتصالان و العلوم عند الاسلام \\
\hline
\end{tabular}

The selection of themes above was based on the scope of material on $A I K 1$ to $A I K 4$ courses. While Arabic language at PTMA has only one course, it is unlikely that everything contained in the four AIK courses is covered in the Arabic language course which is only taught in one semester. The themes above are then harmonized with aspects needed in Arabic language learning as can be seen in Table 3 .

Table 3. Interconnected scope of Arabic language material

\begin{tabular}{|c|c|c|c|}
\hline No. & Topic & Language elements & Scope of each topich \\
\hline 2 & الانسان عند الاسلام & Vocabulary and structure & Vocabulary, conversation, reading material \\
\hline 3 & الايمان و أثره فى الحياة & Vocabulary and structure & Vocabulary, conversation, reading material \\
\hline 4 & التوحيد و أهميته في حباة المسلمين & Vocabulary and structure & Vocabulary, conversation, reading material \\
\hline 5 & منهج العقيدة عند الآسلام & Vocabulary and structure & Vocabulary, conversation, reading material \\
\hline 6 & 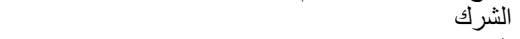 & Vocabulary and structure & Vocabulary, conversation, reading material \\
\hline 7 & العبادة وحقيقتها & Vocabulary and structure & Vocabulary, conversation, reading material \\
\hline 8 & الاخلاق & Vocabulary and structure & Vocabulary, conversation, reading material \\
\hline 9 & المعاملة & Vocabulary and structure & Vocabulary, conversation, reading material \\
\hline 10 & محمدية وتاريخها & Vocabulary and structure & Vocabulary, conversation, reading material \\
\hline 11 & خصائص محمدية & Vocabulary and structure & Vocabulary, conversation, reading material \\
\hline 12 & محمدية وحركة الانسانية & Vocabulary and structure & Vocabulary, conversation, reading material \\
\hline 13 & محمدية وحركة التربية & Vocabulary and structure & Vocabulary, conversation, reading material \\
\hline 14 & التكنولو جيات و المعلومات و الاتصالان و العلوم عند الاسلام & Vocabulary and structure & Vocabulary, conversation, reading material \\
\hline
\end{tabular}

Table 2 explains that there are 14 main themes of Arabic language learning that should be taught to strengthen Al-Islam and Kemuhammadiyahan. Each of these themes must include elements of language namely phonetic, vocabulary, and grammar. Expected student skills include listening skills, speaking skills, and reading skills as shown in Table 3. According to the results of the FGD, writing skills do not need to be taught.

In accordance with the topics agreed upon above, the Arabic language lecturers at PTMA are required to be able to compile vocabulary, conversation material, and reading material in accordance with these themes, so as to produce textbooks according to needs. The preparation of textbooks is the task of educators, whether performed individually or in groups. To strengthen $A I K$ through Arabic language learning at PTMA, the availability of textbooks is a must and as a reference for the scope of subject matter that needs to be mastered to achieve learning objectives. Systematic and neatly printed textbooks can function more permanently than just separate notes, so they can be studied completely outside face-to-face learning to remember forgotten material. In addition, a good textbook can help the teachers in preparing concrete schedules and learning programs, this statement is in accordance with the opinion of Dunlosky, et al. that confirms the existence of learning resources is important because of the limitations of cognitive memory in absorbing and storing learning materials that have been obtained [25].

However, most lecturers are faced with limitations, both time and wide opportunities, adequate facilities, or physical and methodological facilities, to compile a textbook. This condition causes the use of learning resources to be limited to books compiled by other parties, even though it is not necessarily in accordance with the needs and direction of learning development that is expected to strengthen $A I K$.

In fact, none of the books from other parties is fully in accordance with Arabic language learning objectives at PTMA even though the book was compiled by experts from native speakers [26]. Here, lecturers are required to study, evaluate and select the books before they are used in classroom learning. This 
activity must be performed by paying attention to several things: 1) The five criteria for determining the language learning objectives as described; 2) Learning materials allow students to learn independently, not always depending on the teacher; 3) Learning material allows attention to individual differences (furuq fardiyyah) [11], so that it can provide material choices for students who are slow or fast in learning, and provide remedial for underperforming students.

\subsection{Arabic language learning implementation in strengthening $A I K$ at PTMA}

As good as any learning objectives that have been designed and agreed upon then it will not be achieved without accompanied by the implementation of effective, efficient, and quality learning. Therefore, the form of implementation that can then be applied at PTMA based on a study in the FGD: first, the lecturer must have a course unit (SAP) $[27,28]$ which is prepared in accordance with predetermined Arabic language learning. Second, the use of appropriate learning methods [29] and media [30], in learning activities, lecturers are required to be able to use various teaching techniques and media, including textbooks that are appropriate to the situation and conditions of learning. Third, the creation of a conducive learning climate, each lecturer must be able to provide choices for students who have a slow understanding of Arabic language, because the homogeneity of the intellectual level of students at PTMA is very high, it is not uncommon for students who do not recognize Arabic alphabets well. To create a conducive learning atmosphere, it requires the willingness of lecturers to conduct remedial for underperforming students, in addition, lecturers must also be able to organize learning spaces effectively, attractively, comfortably, and safely for the potential development of all students.

Based on the above results, Arabic language learning implementation on PTMA should not be limited to structured learning activities in the classroom, but must also be supported by extracurricular activities to accelerate the improvement of Arabic language abilities that are below average. In accordance with the conditions that exist in the PTMA environment, it is not difficult to implement, especially Arabic language management unit has become part of the AIK at PTMA structure.

\subsection{Arabic language learning evaluation in strengthening AIK at PTMA}

Until now, Arabic language learning evaluation at PTMA was carried out at the end of the semester. For this reason, in an effort to strengthen the Arabic language at PTMA connectivity, evaluations cannot be performed only at the end of learning and at the end of the semester, but there must also be a pretest before students attend lectures, as befits the $A I K$ pretest for prospective students who are enrolled in Muhammadiyah and Aisyiyah Universities.

Skills of students to be measured must also include listening skills, speaking skills and reading skills [31] which are in accordance with the objectives and the material that has been taught. In this case, the assessment instrument that must be prepared by the lecturer demands conformity with the object to be assessed. Until now, the form of Arabic language evaluation is only limited to written questions, so future evaluation requires instruments in the form of recordings to measure listening skills and reading material to measure reading skills in Arabic language.

The existence of tests in learning in addition to knowing the skills of students as well as feedback for educators on the teaching skills [32]. The evaluation has an important role in learning, this statement is based on expert opinions who stated that as a process, learning has three components namely learning objectives, learning implementation, and learning assessment [33], these three components have a close relationship with each other, both directly in a causal relationship, or indirectly in the form of feedback.

Therefore, the evaluation system in Arabic language learning needs to pay attention to the principles: first, integration which means an integral component in the teaching program besides learning objectives, learning material, and learning methods. Second, student involvement [34]; lecturers must be able to generate activities that help students to improve learning methods and outcomes. Evaluation must not be a concern and reduce student enthusiasm for learning. But on the contrary, evaluation must be able to improve student learning quality and outcomes because good evaluation activities can help lecturers improve teaching methods and help students improve learning methods. Third, the coherence which means the evaluation must be related to the teaching material that has been presented and in accordance with the skills to be measured. It is not justified to develop a learning outcome evaluation tool or evaluation of learning achievement that measures material that has not been presented in learning activities.

\section{CONCLUSION}

The strengthening of Al-Islam and Kemuhammadiyahan can be performed through Arabic language learning. However, in reality, Arabic language learning so far requires new construction of four aspects: 1) Learning objectives are directed towards three language competencies; 2) Learning materials are aligned with 
AIK learning; 3) Learning implementation is improved in quality and quantity; 4) Learning evaluation is not limited to cognitive measurements. This study has implications for the Arabic language learning system and Al-Islam and Kemuhammadiyahan which so far have not been connected, so through this study, the two courses have a clear relationship. This study also has implications for the use of learning resources, learning implementation, and evaluation systems. During this time, the learning resources used by PTMA lecturers are the work of Arabic language scientists so with the results of the study, lecturers are required to compile teaching materials in accordance with themes related to $A I K$.

Arabic language learning implementation also has an impact, because lecturers not only teach Arabic language during lecture hours, but lecturers must also be able to set aside time for extracurricular activities in the form of activities arranged by language units at $A I K$ institutions. While the expected form of Arabic language learning evaluation from this study is a pretest Arabic language for every student who will enroll in PTMA. Future Researchers can conduct studies related to the development of learning constructs that are found or conduct experimental studies. With the development of Arabic language learning material construction as the results of this study, researchers will then find more appropriate Arabic language learning resources to strengthen AIK at PTMA. As for the researchers who will use the experimental approach, they will be able to see the effectiveness of the learning construction both in terms of the material, implementation, and evaluation systems.

\section{REFERENCES}

[1] Y. R. Hanny and N. Rizal, "Hidden Curriculum: The Concept of Integrating Islamic Value in Higher Education Accounting at Muhammadiyah on Ulab Albab Perspective," J. Adv. Res. Dyn. Control Syst., vol. 12, no. 1, pp. 113-121, 2020, doi: 10.5373/JARDCS/V12I1/20201018.

[2] A. Aly and M. Nurhakim, "The Role of Transformation in the Curriculum for Sustainability of Schools," Int. J. Innov. Creat. Chang., vol. 12, no. 1, pp. 401-418, 2020, [Online]. Available: www.ijicc.net.

[3] I. Zukdi, "Learning Al-Islam and Kemuhammadiyahan in College Muhammadiyah," in ATLANTIS PRESS: Advances in Social Science, Education and Humanities Research (ASSEHR), 2019, vol. 293, no. Nfeic 2018, pp. 38-41, doi: 10.2991/nfeic-18.2019.8.

[4] M. Ritonga, Asrina, R. Widayanti, F. Alrasi, Julhadi, and S. Halim, "Analysis of Arabic Language Learning at Higher Education Institutions with Multi-Religion Students," Univers. J. Educ. Res., vol. 8, no. 9, pp. 4333-4339, 2020, doi: 10.13189/ujer.2020.080960.

[5] O-R. Ivan, "Foreign Language Learning in the Age of Globalization," Quaestus Multidiscip. Res. J., vol. 1, no. 1, pp. 80-84, 2012.

[6] G. I. Alfataftah and A. G. Jarrar, "Developing Languages to Face Challenges of Globalization and Clash of Civilizations: Arabic Language as an Example," J. Educ. Learn., vol. 7, no. 4, pp. 247-253, 2018, doi: 10.5539/jel.v7n4p247.

[7] S. Kuraedah, H. Insawan, and I. Wahyuni, "The Reality of Arabic Learning Guidance in Indonesian Islamic Senior High Schools," in IOP Conference Series: Earth and Environmental Science, 2018, vol. 175, no. 1-7, doi: 10.1088/1755-1315/175/1/012153.

[8] A. M. Albantani and A. Madkur, "Teaching Arabic in the era of Industrial Revolution 4.0 in Indonesia: Challenges and opportunities," ASEAN J. Community Engagem., vol. 3, no. 2, pp. 198-213, 2019, doi: 10.7454/ajce.v3i2.1063.

[9] N. C. Abdulrahman and E. A. S. Abu-Ayyash, "Linguistic Competence, Communicative Competence and Interactional Competence," J. Adv. Linguist., vol. 10, no. 2, pp. 1600-1616, 2019, doi: 10.24297/ijct.v19i0.8505.

[10] A. W. Ritonga, et al., "E-Learning Process of Maharah Qira'ah in Higher Education during the Covid-19 Pandemic," Int. J. High. Educ., vol. 9, no. 6, pp. 227-235, 2020, doi: 10.5430/ijhe.v9n6p227.

[11] M. Ritonga, et al., "Reformulating the arabic language teaching materials within the framework of generating new cadres of Tarjih and Tajdid Ulama," Int. J. Adv. Sci. Technol., vol. 29, no. 7, pp. 185-190, 2020.

[12] A. J. Fletcher, "Applying Critical Realism in Qualitative Research: Methodology Meets Method," Int. J. Soc. Res. Methodol., vol. 20, no. 2, pp. 181-194, 2017, doi: 10.1080/13645579.2016.1144401.

[13] A. Sirbu, "The significance of language as a tool of communication," in Conference: SEA-CONF 2015 At: CONSTANTA, ROMANIA, 2015, vol. XVIII, no. 2, pp. 405-406, doi: 10.21279/1454-864X.

[14] M. Sarip, "Model of Content and Language Integrated Learning (CLIL) Strategy in Arabic Speaking Subject," Arab. J. Pendidik. Bhs. Arab dan Kebahasaaraban, vol. 6, no. 1, pp. 53-70, 2019.

[15] A. H. El-Omari and H. M. Bataineh, "Problems of Learning Arabic by Non-Arabic Speaking Children: Diagnosis and Treatment," J. Lang. Teach. Res., vol. 9, no. 5, pp. 1095-1100, 2018, doi: 10.17507/jltr.0905.25.

[16] A. Yamanaka and L. Y. Wu, "Rethinking Trends in Instructional Objectives: Exploring the Alignment of Objectives with Activities and Assessment in Higher Education - A Case Study," Int. J. Instr., vol. 7, no. 2, pp. 75-88, 2014, [Online]. Available: www.e-iji.net.

[17] H. Mat and W. M. U. W. Abas, "The Relevance of Arabic Language in Islamic Studies Program: a Case Study of Open University Malaysia (OUM),” J. Educ. Soc. Sci., vol. 5, no. 2, pp. 205-209, 2016, [Online]. Available: https://www.jesoc.com/wp-content/uploads/2016/12/KC5_77.pdf. 
[18] S. Kuraedah, N. A. Mar, and F. Gunawan, "Improving Students' Sense to Learn Language in Islamic Institution of Coastal Area Indonesia," in IOP Conf. Series: Earth and Environmental Science, 2018, pp. 1-7, doi: 10.1088/1755-1315/156/1/012047.

[19] A. A. Aziz, M. A. Ibrahim, M. H. Shaker, and A. M. Nor, "Teaching Technique of Islamic Studies in Higher Learning Institutions for Non-Arabic Speakers: Experience of Faculty of Quranic and Sunnah Studies and Tamhidi Centre, Universiti Sains Islam Malaysia," Univers. J. Educ. Res., vol. 4, no. 4, pp. 755-760, 2016, doi: 10.13189/ujer.2016.040412.

[20] D. A. Hussar, "Learning Objectives.," Int. J. User-Driven Healthc., vol. 2, no. 3, pp. 45-63, 2012, doi: 10.4018/ijudh.2012070105.

[21] J. M. Harackiewicz and C. S. Hulleman, "The Importance of Interest: The Role of Achievement Goals and Task Values in Promoting the Development of Interest," Soc. Personal. Psychol. Compass, vol. 4, no. 1, pp. 42-52, 2010.

[22] E. Rosegard and J. Wilson, "Capturing Students' attention: An Empirical Study," J. Scholarsh. Teach. Learn., vol. 13, no. 5, pp. 1-20, 2013.

[23] K. N. Mohd, A. H. M. Adnan, A. A. Yusof, M. K. Ahmad, and M. A. M. Kamal, "Teaching Arabic Language to Malaysian University Students Using Education Technologies Based on Education 4.0 Principles," in International Invention, Innovative \& Creative (InIIC) Conference, 2019, no. November, pp. 38-51.

[24] Majelis Dikti PP Muhammadiyah, Pedoman Pendidikan Al-Islam Kemuhammadiyahan Perguruan Tinggi Muhammadiyah, Revisi. Yogyakarta: Majelis Pendidikan Tinggi Pimpinan Pusat Muhammadiyah, 2013.

[25] J. Dunlosky, K. A. Rawson, E. J. Marsh, M. J. Nathan, and D. T. Willingham, "Improving Students' Learning With Effective Learning Techniques: Promising Directions From Cognitive and Educational Psychology," Psychol. Sci. Public Interes. Suppl., vol. 14, no. 1, pp. 4-58, 2013, doi: 10.1177/1529100612453266.

[26] Fathurrahman, “Ta'tsir Istikhdam Kitab al-'Arabiyyah Bayn Yadayk li Tarqiyyah Righbah Ta'allum al-Thullab fi Dirasah al-Lughah al-'Arabiyyah," Taqdir, vol. 1, no. 1, pp. 110-128, 2015.

[27] V. Cicek and H. Tok, "Effective Use of Lesson Plans to Enhance Education in U.S. and Turkish Kindergarten thru 12th Grade Public School System: A Comparative Study," Int. J. Teach. Educ., vol. 2, no. 2, pp. 10-20, 2014.

[28] S. Sesiorina, "The Analysis of Teachers' Lesson Plan in Implementing Theme-Based Instruction for Teaching English To Young Learners," J. English Educ., vol. 2, no. 1, pp. 84-95, 2014, [Online]. Available: https://media.neliti.com/media/publications/192273-EN-the-analysis-of-teachers-lesson-plan-in.pdf.

[29] É. M. Granjeiro, "Research-Based Teaching-Learning Method: A Strategy to Motivate and Engage Students in Human Physiology Classes," Adv. Physiol. Educ., vol. 43, no. 4, pp. 553-556, 2019, doi: 10.1152/advan.00034.2019.

[30] Y. D. Puspitarini and M. Hanif, "Using Learning Media to Increase Learning Motivation in Elementary School," Anatol. J. Educ., vol. 4, no. 2, pp. 53-60, 2019, doi: 10.29333/aje.2019.426a.

[31] W. H. Alowaydhi, "Evaluation of Arabic Language Learning Program for Non-Native Speakers in Saudi Electronic University According to Total Quality Standards," J. Educ. Pract., vol. 7, no. 32, pp. 74-90, 2016.

[32] R. Harjanti, Y. Supriyati, and W. Rahayu, "Evaluation of Learning Programs at Elementary School Level of 'Sekolah Alam Indonesia (SAI)'. (Evaluative Research Using Countenance Stake's Model)," Am. J. Educ. Res., vol. 7, no. 2, pp. 125-132, 2019, doi: 10.12691/education-7-2-2.

[33] Z. Zerihun, J. Beishuizen, and W. van Os, "Student Learning Experience as Indicator of Teaching Quality," Educ. Assessment, Eval. Account., vol. 24, no. 2, pp. 99-111, 2012, doi: 10.1007/s11092-011-9140-4.

[34] A. Paolini, "Enhancing Teaching Effectiveness and Student Learning Outcomes," J. Eff. Teach., vol. 15, no. 1, pp. 20-33, 2015, [Online]. Available: https://files.eric.ed.gov/fulltext/EJ1060429.pdf. 